\title{
Development of Visualization Scoreboard for Four Disciplines Execution Visualization of Journal Publication on Mobile Devices
}

\author{
M. Rusli and H. Sutopo
}

\begin{abstract}
This study aims to develop scoreboard visualization as Four Disciplines Execution tools on mobile devices, to improve the smooth processing of the journal publication. By using a scoreboard that can be accessed on a mobile device, the journal editor team can always monitor the achievement of the process that has been obtained, and see what should do to maintain the journal to be published in the certain time. The research was conducted using Multimedia Development Life Cycle according to Luther. The results show that this mobile-based scoreboard visualization can be used properly. The results of this study can be a basic consideration for completing tools to monitor an activity in journal management to avoid the delay in publishing a journal.
\end{abstract}

Index Terms-Four disciplines execution, multimedia, journal, scoreboard, mobile.

\section{INTRODUCTION}

A journal is a periodical publication in the form of a booklet or serial book containing material that people are very interested in when published [1]. When associated with the scientific word behind the word journal, it can be a periodical publication containing scientific material as the main important source of information in the development of science, especially for research. Publication of articles in journals is a requirement that must be done to obtain Bachelor, Master, and Doctoral degrees [2].

Many universities publish journals to facilitate students in order to fulfill the specified requirements to obtain bachelor, master, and doctoral degrees. Many management of the journals are still not good to publish their journals, because of several things: (1) The quality of the paper written does not pay attention to the writing style that applies to the journal; (2) The structure of journal management, which is sometimes only as a complete journal requirement, but has never worked as editors with their knowledge and field experiences; (3) Editor team members who are not all experienced in managing journals; (4) Members of the editorial team that often change over a relatively short period of time; (5) Editor task sometimes is an additional job of the main duty, so that editor prioritizes the main tasks; and (6) Management of the journal does not use professional desktop publishing software to process the journal.

With these constraints, many journals are not published

Manuscript received July 10, 2019; revised September 30, 2019.

M. Rusli and H. Sutopo are with the Institut Teknologi dan Bisnis Kalbis, Jl. Pulomas Selatan Kav. 22, Jakarta Timur, Indonesia (e-mail muhammad.rusli@ kalbis.ac.id, hadi.sutopo@ kalbis.ac.id). according to a predetermined schedule, even lacking the final manuscript that can be processed by the design section for publication. If the manuscript received by the editor of the author is sufficient, but after being investigated there are some problems that must be returned to the author, because the editor cannot cope on his own. It becomes the problem because the publishing time might be delayed. Based on the background above, the problem could be solved by creating a scoreboard to remind the schedule of processing the papers that must be done. Visualization is a computerized technique in creating images, diagrams, or animations to communicate a message [3].

This study aims to create a multimedia-based [4] scoreboard as an 4DX tool to improve journal management using mobile device. This research is conducted based on the prior research entitled Multimedia Based Scoreboard Development of Four Disciplines of Execution for Journal Publication, that was presented in 8th International Conference on Knowledge and Smart Technology (KST) [4]. The results of the prior research was a multimedia-based visualization [3] that run on a computer, with the development using ActionScript 2.

This recent study continued the visualization that can run on mobile device. To develop multimedia visualization that can be accessed on a mobile device, should use ActionScript 3 [5]. Application which is developed in ActionScript 2 scripting language, can only be run using Flash Player that is not supported for mobile devices, while ActionScript 3 supports its use on various platforms and mobile devices.

\section{A. Journal Publication}

Journals have special characteristics that are not found in magazines, because the papers are written by people who are experts in their certain disciplines [6]. Articles written are usually the results of research accompanied by illustrations in the form of diagrams or graphs. Scientific journals are an important main source of information in the development of science [7], unfortunately until now in Indonesia there have not been many producing reputable international journals indexed by Thomson Reuters. Scientific journals managed by universities in Indonesia are still experiencing difficulties to be upgraded to international journals [2].

Journal publishing system involves four parties, namely customers, writers, publishers, and printing [1]. Customers are journal users or customers who are interested in the contents and physical form of the journal. The publication of a journal is carried out through several stages, namely the text processing stage, the design processing stage and the printing stage. Managing journals requires human resources who 
have various competencies such as editing and design, and using professional desktop publishing software [8], [9]. Publishers usually have several sections that handle journal processing at the editorial stage. With the development of desktop publishing the work of the pre-printed parts included in the printing press is currently carried out by the publisher. This section is called design processing, or production part, or also still uses prepress [1]. The design processing section in the publisher is tasked with making the design and layout of the journal pages prepared for printing. Not infrequently this section handles film making from layout results, so the material submitted to the printing press is film. But with the development of technology at this time printing does not require films so the design section produces files in pdf format to be submitted to printing. This way is done to maintain the quality of the journal to be printed, because the accuracy of the printouts can be controlled by the publisher. The prepress part of the printing press that previously handled the layout and film now only regulates the imposition and makes a plate for printing. Imposition is the arrangement of pages that will fill one sheet of paper in printing [10]. Several sheets of paper were then folded and bound to produce a journal. Another system of journal is online journal system that the managing, submitting articles are conducted online. An online journal is a periodical publication which is published in electronic format, usually on the Internet. Some journals are only available in electronic format and can be downloaded from the journal website [11] .

\section{B. Four Disciplines Execution}

Four Disciplines Execution (4DX) is the result of years of research at various global companies, conducted by Stephan R. Covery. The point is more or less, that we call Four Disciplines Execution as four tips in the discipline of execution [12], namely: (1) Focus in a Wildly Important Goal. This means that more or less is to focus on the most important goals. Wildly Important Goal is the most basic main goal. If this goal fails to be achieved, whatever form of achievement is, then it does not mean anything at all. Wildly Important Goals may not be too much, because some of the goals can be achieved. Simply take a little goal, and focus on implementing it. (2) Act on the Lead Measures. The point is to make a commitment that can bring organization to achieve the Wildly Important Goal. Lead Measures are adjusted easily, in contrast to the Wildly Important Goal which is difficult to be changed. (3) Keep a Compelling Scoreboard. Therefore, organization requires to make a scoreboard in addition to the work plan that has motivational value. The characteristics of a scoreboard are: motivational, simple, can be updated at any time, and can be seen by all employees at any time. It should be able to explain Wildly Important Goal and Lead Measure in a simple manner, and achievements at all times. (4) Create a Cadence of Accountability. It is creating a rhythm of accountability. Within a certain period of time, everyone must agree on the talks about the progress of achieving goals.

\section{Mobile Device}

The word mobile means moving device. So that the understanding that mobile application that can be run even if the user moves or because the user has moved to another location. Programming an application for using on mobile device Is not too different from conventional programming on PC. The characteristic aspects of mobile devices often affect the architecture and implementation of the application. In moving application programming various technical aspects of the device are more prominent because they have many limitations compared to conventional computers. [13] On a global scale, many people read in an incredible pace like never before. So the point is people spend a great deal of time glued to a screen, reading digital media, social networks and other discussion forums. [14]. Although the internet is considered a crucial part of contemporary life, it also represents the state of emergency in risky behaviour. Many studies show that people can be addicted to internet, resulting harmful effects on social behaviour, habits and abilities [15].

\section{RESEARCH METHOD}

\section{A. Method}

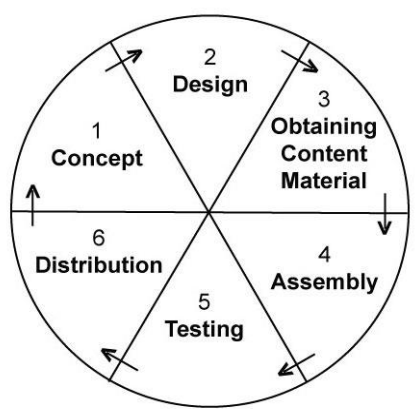

Fig. 1. Six stages of multimedia development life cycle according to Luther.

The multimedia development method uses in this study is Multimedia Development Life Cycle (MDLC) [4]. Authoring tends to be like making a film, and there are several steps in developing it. Multimedia Development Life Cycle is a multimedia development method, which involves six major steps as presented in Fig. 1, as follows: (1) Concept. The objectives for the project are defined, and the type of application is determined. In multimedia, this stage indicates where the producer decides the type of multimedia and the subject to be made. (2) Design. Design is the process of determining in detail what will be done in a multimedia project and how it will be presented. This stage includes script writing, making storyboard and navigation structure, as well as several other design steps. (3) Obtaining Content Material. During this stage all data, audio, video and images for the project are collected in appropriate digital format. In multimedia development, the material that is obtained at this stage will be used at the production stage, where all scenes for mobile application are set. (4) Assembly. At this stage, the entire project is built, and programming is done to create multimedia application. At this stage the authoring tool is equipped with multimedia programming capabilities. (5) Testing. During testing, the application is executed and checked to ensure that multimedia development is carried out according to what has been designed. Tests are carried out to fix whether the application can be run on a computer with factory output and different screen resolutions. In addition, 
respondents also tested whether the tutorials made on the application can be understood easily. (6) Distribution. In this step, the developed application is duplicated and given to the user to use. Distribution can be in various forms, both in the form of CD-ROMs, mobile devices, and web sites.

\section{B. Location and Respondents}

This research is conducted to develop multimedia-based scoreboard for 4DX on mobile devices. The data collection locations are at four universities in Indonesia, while the respondents are journal teams and reviewers. The purpose of this study is to make it easier for journal managers to monitor the work they are doing.

After the early product was completed, then an evaluation was carried out by three experts [16] that have competencies in journal management, visual communication design, and information technology.

\section{RESUlTS AND DISCUSSION}

\section{A. Concept}

In this stage, identification of needs was carried out, studying literature and researching in the management of a journal publisher. This initial study was carried out in the Kalbiscientia journal. Respondents were managers of the Kalbiscientia journal consisting of the Editor-in-Chief, Editors, Layout Editor, and Corrector. Preliminary research was conducted to obtain information on the requirements for making application.

The equipment used to produce scoreboard visualization was available, namely a notebook with 8 GB RAM and a 500 GB hard drive and equipped with a scanner and a printer. While the system software was Windows 7 Professional with Adobe Flash Professional CS6 authoring tool. Human resources to make products consist of animators, multimedia programmers, multimedia designers, and staffs. In this study, human resources from outside were not needed, because researchers can do all the work.

After obtaining information on the initial research and data collection, the development of a scoreboard visualization was carried out by taking into account the following matters: (1) The Overview material explained the reasons why journals were needed, including to fulfill the need for article publication, which was a requirement for student graduation [2]. (2) Types of journals included summarizing the national and international journals, along with their requirements recognized by the Higher Education. Indexing was a measure of how well the quality of a journal was according to international standard. (3) Journal indexing material included an explanation of international indexing institutions with their rankings. (4) Journal management material included the processing of journals carried out in the editor consisting of several people. (5) Material of journal scoreboard was explanation dealing with journal scoreboard that can be used to monitor the progress of journal management. (6) Material of scoreboard visualization contained visualization that could be tried by the users, according to the characteristics of the journal, namely the number of articles in an issue was 6,12 , or 20 ; the journal was published twice, 3 times or 6 times a year.

\section{B. Design}

\section{1) Content planning}

Material of Scoreboard Visualization presentation based on the sequence of discussion according to the needs of scoreboard visualization that could be used by members of the journal management team, namely (1) Overview, (2) Types of Journal, (3) Journal Indexing, (4) Journal Processing, (5) Journal Scoreboard and ( 6) Scoreboard Visualization.

\section{2) Mobile-based product planning}

The conceptual model was an embodiment of multimedia and scoreboard material. The development of multimedia-based mobile application, especially scoreboard visualization, considered several things, namely: (1) Audience. Users of this application were editorial teams. (2) Output equipment. Because of the visualization material would be used by team members who always worked with computers, a suitable format was required for interactive use on the mobile screen. (3) Picture. Tutorial was provided with images, such as backgrounds and illustrations that needed to be made using graphical software. (4) Audio. Tutorial did not use special audio recordings, nor audio as a part of video. (5) Video. There was not any video; (6) Animation. Animation was displayed in accordance with the material discussed, so users could see the form of animation that was being made. (7) Interactive tools. Tutorial required an interactive tool using the touch screen to move an object to a certain location.

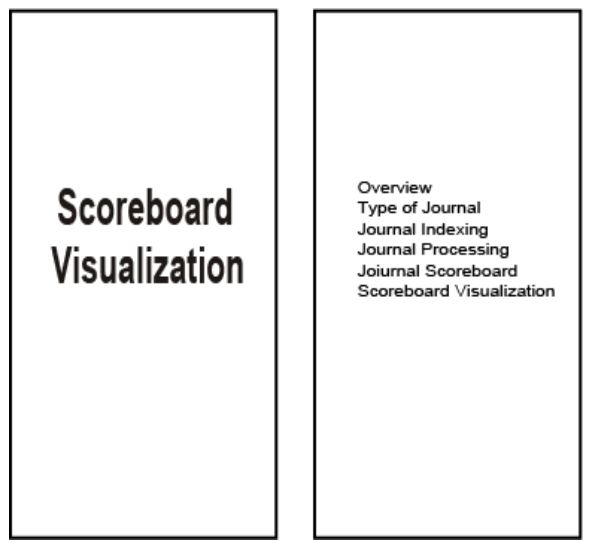

Fig. 2. Storyboard of scene 1 and scene 3.

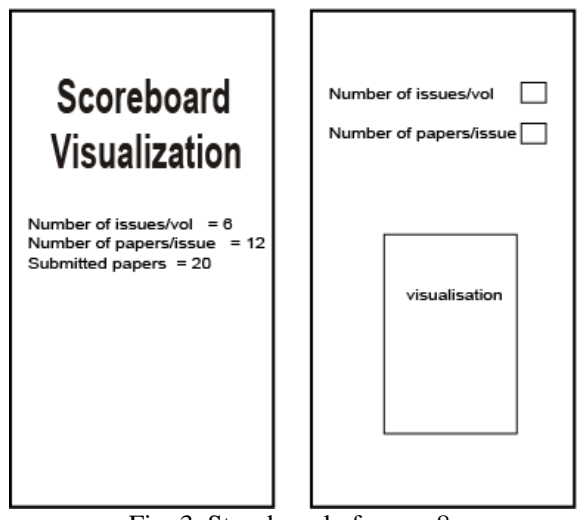

Fig. 3. Storyboard of scene 8 .

Production was the stage where all multimedia objects were created. Making application based on storyboard as cam 
be seen in Fig. 2 and Fig. 3, and navigation structure as can be seen in Fig. 4, was originated from the design stage. At the design stage a storyboard was created that described the appearance of each scene. Because the interactive for the application was not simple, it required a navigation structure that could be used to determine links from a scene to another one. After creating multimedia application, the APK file was transferred to mobile devices to be run.

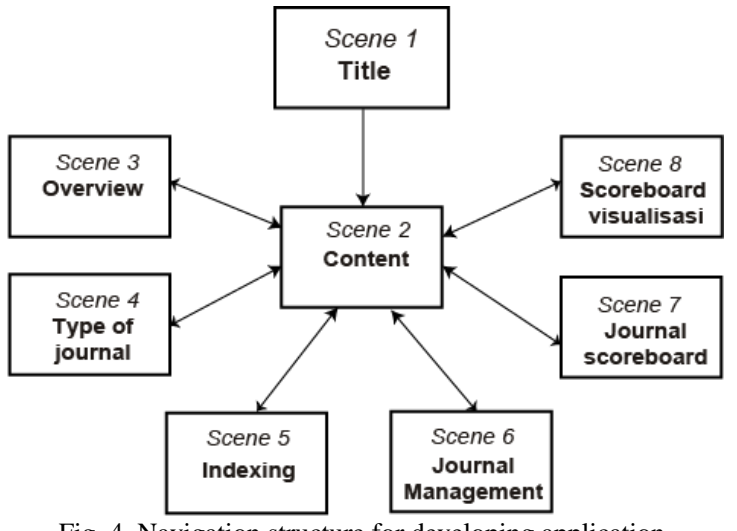

Fig. 4. Navigation structure for developing application.

\section{3) Obtaining content material}

Collecting material could be done parallel with the production stage. At this stage, material collection such as images, animations, audios, videos and others were needed for the next stage. If the material sought was not found, it must be made using appropriate software.

\section{4) Assembly}

The production stage was the stage where all multimedia objects were created, that making application based on storyboard and navigation structure. With the storyboard, each scene could be displayed, while the navigation structure was used to determine the links between one scene and the other scenes. At the stage of production an authoring tool was needed to create multimedia application. Visualization of scoreboard had a lot of interactive [17] and complexity, so a simple authoring tool could not be used to handle it. To overcome this problem was by programming using ActionScript which was part of the features in Adobe Flash Professional authoring [18]. Because the application was planned to be used on mobile devices that could be downloaded from Google Play or Play Store, then it was important for programming using ActionScript 3.

\section{5) Testing}
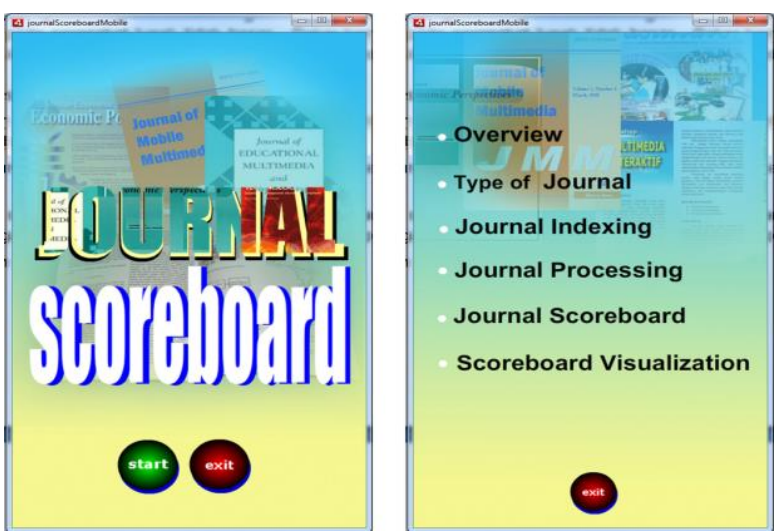

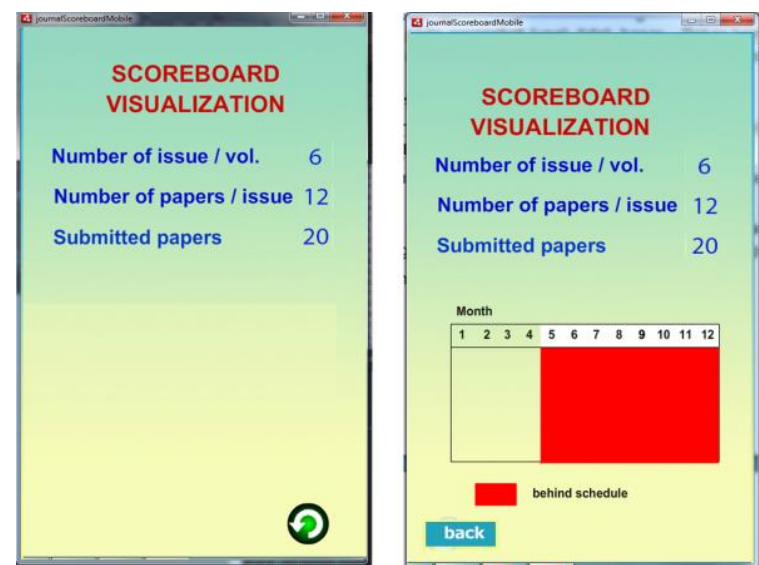

Fig. 5. Several displays of the application.

The testing was carried out by the research team after the Assembly stage, which checked whether the application produced was in accordance with the storyboard and navigation structure made at the design stage. In addition, testing was done using mobile devices with different brands, resolutions and orientations. Fig. 5 shows the appearance of the application that run on a mobile.

a) Peer-to-peer evaluation

Evaluation of colleagues who had adequate competence in the field of journal management was carried out during the production process and was almost complete. Based on peer evaluations [11], to complete the initial product, the researcher made improvements as follows: (1) In the initial section was less interesting because only static text, the title should be animated. (2) The font for the explanation of the subject was too small to be read and was not contrast because it used a small font in white color. For making the text to be clear, the font size was enlarged. (3) Peers stated that Help was needed as a guide, except instructions in the full tutorial for all topics. With the consideration that users could use the application and get information by looking at animation, visualization and text at the same time, then it was better to display integrated animations with text.

\section{b) Expert judgment}

After the initial product was completed, then an evaluation was carried out by three experts [16], namely the journal management, visual communication design, and information technology.

The three experts were:

\begin{tabular}{|l|l|l|l|}
\hline No. & \multicolumn{1}{|c|}{ Name } & \multicolumn{1}{|c|}{ Institution } & \multicolumn{1}{|c|}{ Job Title } \\
\hline 1 & $\begin{array}{l}\text { Sularso Budi } \\
\text { Laksono }\end{array}$ & $\begin{array}{l}\text { Universitas Persada } \\
\text { Indonesia YAI }\end{array}$ & $\begin{array}{l}\text { Reviewer of } \\
\text { Jurnal Teknologi } \\
\text { Pendidikan }\end{array}$ \\
\hline 2 & Yuniar & $\begin{array}{l}\text { Institut Teknologi dan } \\
\text { Bisnis Kalbis }\end{array}$ & $\begin{array}{l}\text { Expert of Visual } \\
\text { Communication } \\
\text { Design }\end{array}$ \\
\hline 3 & $\begin{array}{l}\text { Dwipo } \\
\text { Setyantoro }\end{array}$ & $\begin{array}{l}\text { Universitas Persada } \\
\text { Indonesia YAI }\end{array}$ & $\begin{array}{l}\text { Expert of } \\
\text { Information } \\
\text { Technology }\end{array}$ \\
\hline
\end{tabular}

In the section about the objective of research, there was not any comment nor suggestion from journal management expert and visual communication design expert. Information technology expert said that the purpose of the application was specific. 
In the section about multimedia visualization, there was not any comment nor suggestion from journal management expert and visual communication design expert. Information technology expert said that the choice of the number of articles / number of publications / volumes was in accordance with most journal publishers generally.

Journal management expert stated that generally installation on mobile device was quite easy. The next and back buttons should be replaced with buttons with arrows, so that the text "next" and "back" could be removed considering the small space in the display. Visual communication design expert said that the animation was quite good, while the text needed attention and should be made bold with other colors. Information technology expert said that the text should be enlarged, so that it was easier to read on a mobile device with a small resolution. Also, journal management expert said as the same.

\section{c) Product revision}

Based on comments and suggestions from experts in journal management, visual communication design, and information technology, researchers made improvements as follows: (1) The number of articles in an issue, and number of volumes was proper in accordance with most journal publishers, so it did not need to be changed. (2) The next and back buttons had been replaced with a buttons with an arrows, so that the text "next" and "back" could be removed considering the small space in the display, as can be seen in Fig. 6. (3) Text had been changed into bold style with other colors. (4) Text could not be zoomed because it was not a web-based application, but based on animation. This was similar to many game application that could not be zoomed.

\section{d) Main field testing}

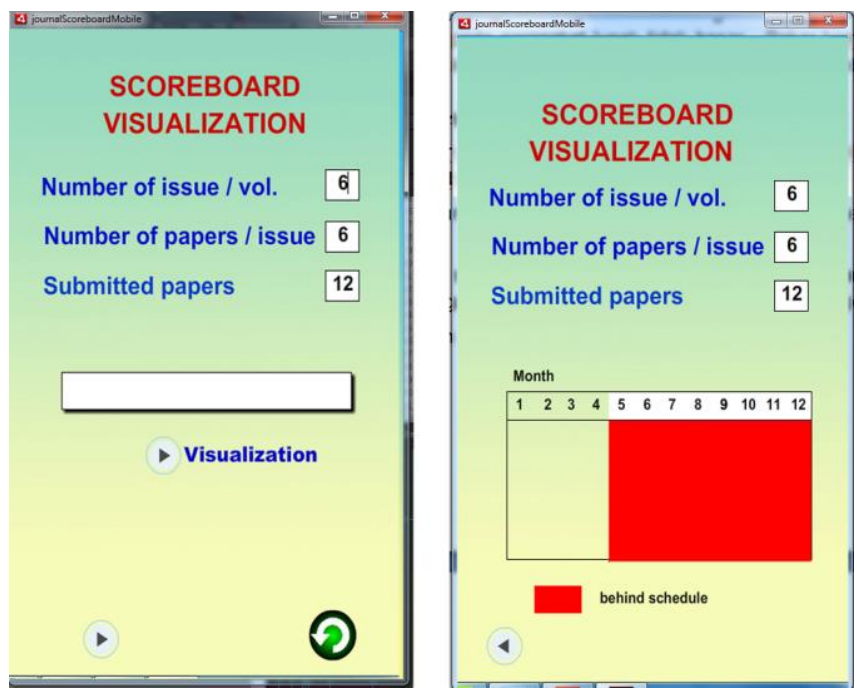

Fig. 6. Revision of scoreboard visualization.

Feasibility of products to use. For managing journals, generally one journal number consisted of 6 articles, 12 articles, or 20 articles. The evaluation stated that $36.36 \%$ of respondents agreed, while those who disagreed were $63.64 \%$. Journal publishing period in a year was twice, 3 times, 4 times, and 6 times. The evaluation indicated that $27.27 \%$ of respondents agreed, while $72.73 \%$ of respondents disagreed. In general, the manuscripts received from the authors had followed the style of the journal, $00.00 \%$ of respondents agreed, while $100 \%$ of respondents disagreed. The review of the manuscript by the sustainable partners was carried out within 1 month, $72.73 \%$ of respondents agreed, while $27.28 \%$ of respondents disagreed. The design process by layout editor required 1 month before it was published, $81.82 \%$ of respondents agreed, while $18.18 \%$ of respondents disagreed.

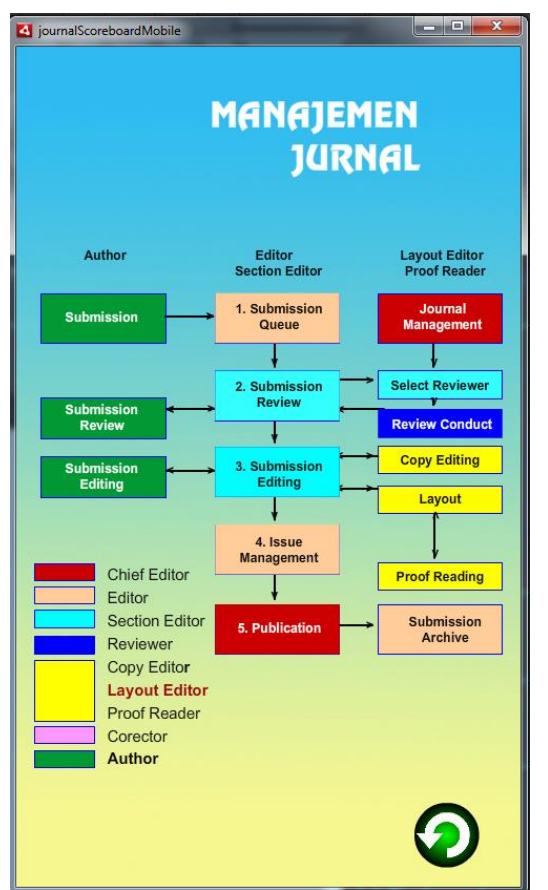

Fig. 7. The image or text is enlarged so that it is easy to read.

For the scoreboard visualization application based on mobile, the material in the application was clear, $100 \%$ of respondents agreed whereas those who disagree was $00.00 \%$. The material in the application was complete, $18.30 \%$ of respondents agreed, while $81.70 \%$ of respondents disagreed. Easy to install application, $72.73 \%$ of respondents agreed, while $36.27 \%$ of respondents disagreed. Easy to use application, $100 \%$ of respondents agreed while those who disagreed was $00.00 \%$. The fonts in the application were easy to read, $27.30 \%$ of respondents agreed while $72.70 \%$ of respondents disagreed. Balance display layout, $81.82 \%$ of respondents agreed, while $18.18 \%$ of respondents disagreed. The font color contrasts with the background, $63.63 \%$ of respondents agreed, while $36.37 \%$ disagreed. Visualization was understood easily, $81.82 \%$ of respondents agreed, while $18.18 \%$ of respondents disagreed.

Some revision should be done to improve the application, as follows:

- Material in the application $18.30 \%$ of respondents who agreed while respondents who disagreed as much as $81.70 \%$ meant that the material in the application must be added or completed.

- Fonts in the application were easy to read, $27.30 \%$ of respondents who agreed while those who disagreed as much as $72.70 \%$ indicated that fonts in the application still needed to be changed to be reading ease.

- The font color contrasts with the background, $63.63 \%$ of respondents agreed, while $36.37 \%$ disagreed. It meant that the color still needed to be corrected.

- Some respondents thought that the application could be 
flexible and used for a variety of numbers in one volume, the number of articles in one issue and the number of articles that had been received by the management team.

\section{e) Product revision}

At this stage, the researchers made improvements to the results of the field trials, as can be seen in Fig. 6 .

\begin{tabular}{|l|l|l|}
\hline No & \multicolumn{1}{|c|}{ Problem } & \multicolumn{1}{c|}{ Revise } \\
\hline 1 & The material was too simple & $\begin{array}{l}\text { Adding the material to be } \\
\text { completed }\end{array}$ \\
\hline 2 & $\begin{array}{l}\text { The font size was too small, } \\
\text { so it was hard to be read }\end{array}$ & $\begin{array}{l}\text { The font was changed } \\
\text { into 23 pt. from the prior } \\
20 \text { pt. }\end{array}$ \\
\hline 3 & $\begin{array}{l}\text { Some of the letters were not } \\
\text { clear because of the } \\
\text { background color }\end{array}$ & $\begin{array}{l}\text { The background color } \\
\text { was changed to be lighter }\end{array}$ \\
\hline 4 & $\begin{array}{l}\text { There were only three kinds } \\
\text { of page numbers 6,12 and 20 }\end{array}$ & $\begin{array}{l}\text { Number of pages can be } \\
\text { input flexibility }\end{array}$ \\
\hline
\end{tabular}

\section{CONCLUSION}

Visualization of scoreboard reminds journal team members to the final script completion schedule that must be done by the manuscript section to be submitted to the design section of the journal management. After completing the scoreboard visualization application using a mobile device involving journal management expert, visual communication design expert, and information technology expert, as well as the management team from various journals, it can be concluded that the application can be used for monitoring journal management.

\section{ACKNOWLEDGEMENT}

Kalbis Insstitute supported the research well, therefore authors thank to the institution. Authors would like to thank to all of colleagues for their supporting in survey data collection.

\section{REFERENCES}

[1] A. H. Sutopo, Desain Brosur dan Majalah Dengan Adobe in Design, Jakarta: Elex Media Komputindo, 2007.

[2] "Surat dirjen dikti No. 152/E/T/2012: Wajib publikasi ilmiah BAGI S1/S2/S3.” Dirjen Dikti, Jakarta, 2012.

[3] H. Sutopo, "Multimedia based instructional development: Bubble sort visualization," in Proc. the IEEE International Conference on Software Engineering and Service Sciences, ICSESS, 2015.

[4] M. Rusli and H. Sutopo, "Multimedia based scoreboard development of four disciplines of execution for journal publication," in Proc. the 2016 8th International Conference on Knowledge and Smart Technology, KST 2016, 2016.

[5] V. Brossier, Developing Android Applications with Adobe AIR: An Action Script Developer's Guide to Building Android Applications, 1st ed. O'Reilly Media, 2011.

[6] What's a journals? University of Victoria Library. [Online]. Available: https://www.uvic.ca/library/research/tips/journal/index.php

[7] What Are Scientific Journals? American Psychological Association. [Online].

Available: https://www.apa.org/advocacy/research/defending-research/scientificjournals
[8] W. L. Belcher. How to manage a peer-reviewed journal. [Online]. Available: https://wendybelcher.com/writing-advice/manage-peer-reviewed-jour nal/

[9] H. Sofyandi, Manajemen Sumber Daya Manusia, Jakarta: Graha Ilmu, 2008.

[10] W. Collins. Graphic design and print production fundamental. [Online] Available: https://opentextbc.ca/graphicdesign/chapter/5-6-imposition

[11] What is an electronic journal? SOAS University of London. [Online] Available: https://www.soas.ac.uk/library/resources/ejournals/about/

[12] C. McChesney and S. Covey, The 4 Discipline Of Execution, New York: Dunamis, 2012.

[13] H. Sutopo and F. Abadi, "Mobile multimedia-based tourism promotion development," in Proc. the 2018 2nd International Conference on Computer Science and Artificial Intelligence, 2018, pp. 451-454.

[14] S. Papadakis and M. Kalogiannakis, "Combining mobile technologies in environmental education: A Greek case study," Int. J. Mob. Learn. Organ., vol. 11, no. 3, pp. 256-277, 2017.

[15] J. Grajczonek, "Early childhood education.," J. Relig. Educ., vol. 59 , no. 3, p. 3, 2011.

[16] E. Baauw, M. M. Bekker, and W. Barendregt. A structured expert evaluation method for the evaluation of children's computer games. [Online]. Available: https://www.researchgate.net/publication/221054336_A_Structured Expert_Evaluation_Method_for_the_Evaluation_of_Children's_Com puter_Games

[17] T. Vaughan, Multimedia Making It Work, Yogyakarta: Andi Publisher, 2006.

[18] D. Ypenburg, Visual Quickstart Guide ActionScript 3.0, Barkeley, CA: Peachpit Press, 2009.

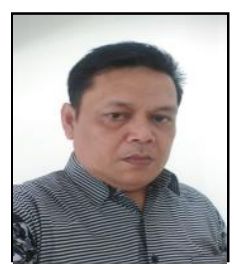

Muhammad Rusli was born in Makassar, Indonesia on 18 July 1968. He obtained the master of management at Institut Teknologi dan Bisnis Kalbis, Jakarta, graduated in 2011. He obtained the bachelor at Universitas Negeri Makassar, Indonesia, majoring in mathematics.

$\mathrm{He}$ has been lecturing mathematics at Institut Teknologi dan Bisnis Kalbis and some other universities in Jakarta, Indonesia since 1994. He wrote a book on discrete mathematics, and was published by Graha Ilmu Publisher, Indonesia. Many papers were presented in international conferences and published in many international journals and proceedings. His current research interests are information technology and mathematics.

Mr. Rusli is a member of Indonesian Association of Higher Education in Indonesia that is called APTIKOM. He is a reviewer and a member of board of editor of journals that were published in Indonesia

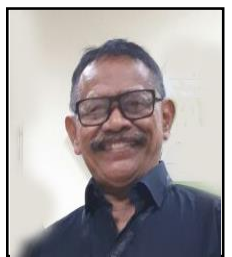

Hadi Sutopo was born in Cilacap, Indonesia on 15 April 1945. He is a doctor of education in educationa technology at the State University of Jakarta, graduated in November 2009. In 1998 he earned the master of information systems at Post Graduate Program Gunadarma University, Jakarta. In 1995 he graduated from the Universitas Persada Indonesia YAI. Jakarta, majoring in informatics.

$\mathrm{He}$ is currently a lecturer on the subjects of multimedia and game development at Institut Teknologi dan Bisnis Kalbis. $\mathrm{He}$ has been a facilitator of multimedia, computer graphics, and research methodology in many schools, universities, and organizations. He wrote many books and papers on multimedia and educational technology that were published in many international journals. He has been a reviewer of many international journals and conference on the subject of multimedia and educational technology. His current research focuses on multimedia, computer graphics, and various aspects of educational technology.

Dr. Sutopo is a senior member of Institute of Electrical and Electronics Engineers (IEEE), senior member of International Association of Computer Science and Information Technology (IACSIT), and member of Association of Education and Communication Technology (AECT). 